\title{
Abbas el-Akkâd Örnekliğinde Dîvan Ekolü Şairlerinde Ümitsizlik Teması
}

\section{The Theme of "Hopelessness" Among the Diwan School Poets: The Example of Abbas al-Akkad}

\author{
Rümeysa Zeynep UYLAŞ ${ }^{1}$
}

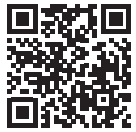

'Marmara Üniversitesi, Sosyal Bilimler Enstitüsü, Arap Dili ve Belagatı Anabilim Dalı, İstanbul, Türkiye

ORCID: R.Y.U. 0000-0002-4833-4072

Sorumlu yazar/Corresponding author: Rümeysa Zeynep UYLAȘ (Doktora Öğrencisi), Marmara Üniversitesi, Sosyal Bilimler Enstitüsü, Arap Dili ve Belagatı Anabilim Dalı, İstanbul,

Türkiye

E-posta: rumeysazeynep@gmail.com

Başvuru/Submitted: 18.08.2021

Revizyon Talebi/Revision Requested:

01.12.2021

Son Revizyon/Last Revision Received:

15.12.2021

Kabul/Accepted: 10.02.2022

Online Yayın/Published Online: 04.03.2022

Atıf/Citation: Uylas, Rumeysa Zeynep. "Abbas el-Akkâd Örnekliğinde Dîvan Ekolü Şairlerinde Ümitsizlik Teması." Şarkiyat Mecmuası - Journal of Oriental Studies 40. Advanced Online Publication. https://doi.org/10.26650/jos.984132 öz

Osmanlı Devleti'nin yıkılması sonucunda yeni devletlerin oluşması ve dünyaya hâkim olan milliyetçilik akımı, birçok yeni yönelişi ve ekolü beraberinde getirdi. Arap toplumunda kitleleri etkileyen en önemli araç ve hayatın odak noktası olan şiir, modern dönemde toplumun bir yansıması olarak milliyetçi ve siyasi şiir, hemen ardından Fransız ve İngiliz işgallerinin doğurduğu sömürge karşıtı şiir olarak karşımıza çıkar. Özellikle 19. yy.'dan sonra edebiyatçıları, fikir insanları ve eserleri dikkatle takip edilen Mısır ve Suriye, edebi, siyasi ve ideolojik akımlara öncülük etti. 19. yy. sonlarında Arap şiirinin ihyası amacıyla Barûdî (1839-1904), Ahmed Şevki (1868-1932) ve Hâfız Ibrahim (1871-1932) tarafından kurulan NeoKlasik Ekol, yapısında ve konularında kadim şiiri örnek almıştır. Peşlerinden gelen Abbas el-Akkâd (1889-1964), Abdülkadir Mâzinî (1890-1949) ve Abdurrahman Şükrî (1886-1958)'den oluşan Dîvan Ekolü şairleri ise, Arap şiirinde ve edebi tenkitte bir dizi yenileşme gerçekleştirmişler, kendilerinden sonra gelen Mehcer ve Apollo gibi modern edebi akımlara birçok konuda önderlik etmişlerdir. Bu ekol, Arap edebiyatında modern şiire yön veren medrese olup şiirin muhtevasında, hatta şiir algısında kadim şiirden tamamen farklı bir bakış açısına sahiptir. Dîvan Ekolüne göre, şiirin değeri şairin duygularının samimiyeti (sıdku'ş-şi'r) ölçüsündedir. Döneme hâkim olan sosyal, siyasi çıkmazlar ve belirsizlikler, ayrıca beslendikleri Batılı romantik şairlerin etkisiyle öne çıkan ümitsizlik, şiirlerinde açıkça görülmektedir. Bu makalede yeni bir şiir geleneği oluşturan ekolün en güçlü temsilcisi Akkâd örnekliğinde, acı çeken, özgürlük arayışındaki bir halkın hissettiği ümitsizlik temasının Dîvan Ekolü şairlerindeki yansımasını ele aldık.

Anahtar kelimeler: Modern Arap Şiiri, Dîvan Ekolü, Abbas el-Akkâd, Şiirde Ümitsizlik Teması

\section{ABSTRACT}

The formation of a new literary movement-as a result of the collapse of the Ottoman Empire and the nationalist movement that dominated the world-gave rise to many new tendencies and schools of thought. Poetry, the most important tool influencing the Arab masses appeared as nationalist and political poetry, 
as a reflection of modern society, and as anti-colonial poetry born of the French and British occupations. Especially after the 19th century, the literati and intellectuals in Egypt and Syria carefully followed the pioneered literary, political, and ideological movements. For example, there was the Neoclassical School formed by Baroudi (1839-1904), Ahmed Shawqy (1868-1932), and Hafez Ibrahim (1871-1932). It focused on the revival of Arabic poetry and considered ancient poetry as an inspiration for its structure and subjects. Subsequently, the poets of the Diwan School, consisting of Abbas al-Akkad (1889-1964), Ibrahim Abdel Rahman Shokry (1886-1958), and Abdal-Qadir al-Mazny (1890-1949), performed a series of innovations in Arabic poetry and literary criticism, and led the modern literary movements that followed, such as Mahjar and Apollo. This movement, which focuses on modern poetry in Arabic literature, includes a completely different perspective from ancient poetry. Specifically, the value of poetry is in the sincerity of the poet's feelings (sidku'ş-şi'r). The theme of "hopelessness," which came to the forefront because of the social and political dilemmas and uncertainties that dominated the period and the influence of Western Romantic poets, is clearly seen in their poems. Thus, we examine this particular theme by using the example of Abbas al-Akkad, the strongest representative of this school.

Keywords: Modern Arabic Poetry, Diwan School, Abbas el-Akkad, The Theme of "Hopelessness" in Poetry

\section{EXTENDED ABSTRACT}

The social change that occurred at the end of the 19th century and the cultural contact between the Arab civilization and the West led to the formation of modern literary movements. The Diwan School, in particular, offers an innovative perspective of next-generation poets by considering the aspects of previous periods. As the strongest representative of this school, the example of Abbas al-Akkad (1889-1964) and the theme of "hopelessness" is critical. In order to better understand the concept of poetry, the historical, literary, and political conditions surrounding this poet are also mentioned.

In general, there is significant literature in the Arab world on Abbas al-Akkad (who produced many works in different genres) and his influence on modern literature. However, this study on Akkad is limited to the theme of "hopelessness," which came to the forefront in the poems of the Diwan School. This school, represented by Abbas al-Akkad, Ibrahim Abdel Rahman Shokry (1886-1958), and Abdel-Qadir al-Mazny (1890-1949), made a series of innovations in both poetry and criticism, and pioneered the Apollo and Mahjar Schools that followed. Moreover, these three poets brought a different perspective to Arabic poetry as a whole. However, the group disbanded soon after its establishment (due to the plagiarism debate and mutual criticism between Shokry and Mazny), leaving Akkad to singlehandedly act as the "flag bearer" of this school. Thus, the present study examines the background of the Diwan School, its main features, and Akkad's poetry in light of the aforementioned theme.

After Muhammad Ali Pasha (1769-1849) took over as the de facto leader of Egypt, education in foreign languages emerged, while the literary and intellectual heritage of the West was transferred into the Arabic literature. Meanwhile, the efforts of libertarian intellectual poets and writers, who aimed to find their own identity, led to the formation of many literary schools. For example, the Neoclassical School, led by Baroudi (1839-1904) and considered as 
the beginning of modern poetry, aimed to return the poetry of the Arab heritage to its superior age. While Baroudi and his students Ahmed Shawqy (1868-1932), Hafez Ibrahim (1871-1932), and Khalil Motran (1869-1949) mainly adhered to classical Arabic poetry, they frequently included national feelings, due to the conjuncture brought about by the period. In this regard, by expressing the feelings, sorrows, and hopes of the people, they brought innovations in the subjects of their poems.

When examining the main features of the Diwan School, we can see that they are simple in their expressions, they regard meaning as superior to words and siga (poetic flow), and they focus on the human spirit down to the smallest detail. Unlike the previous Neoclassical School, they did not write praise poems to kings, viziers, or rulers. Instead, they focused on the themes of pessimism and despair in the world. While the disappointments experienced as a result of the French Revolution's failure to provide the expected libertarian, democratic, and prosperous life, the same crisis was met with the political uncertainties and future concerns created by the colonial environment in Arab countries.

As for this school, sincere expression of emotions in poetry was its most important guide. For this reason, Akkad rejected his poems to be a defense of any ideology, and criticized the previous schools for such views. According to Akkad, poetry should be used as a tool in the expression of "hopelessness," especially in a society that has been successively colonized by Western countries. On the other hand, it should also be used to energize a society to overcome such emotions. In the present study, there are examples in which melancholy, hopelessness, and sadness prevail in all Diwan School poets. In particular, in Akkad's poetry, we see that he does not stagnate in "hopelessness" in order to achieve his societal goal. On the contrary, he instills hope by talking about his belief about the "good days to come." For example, after the "hopelessness" in his couplets bayits, in which he expressed the problems of the suffering and oppressed masses, he aimed to transform them with his poetry and give them hope. It should be noted that this school did not disappear under the influence of Western Romanticism, and the literature, infused with Islamic philosophy, guided future generations of writers. 


\section{Giriş}

Modern Arap şiiri klasik Arap şiirinin vezin ve kafiyesini muhafaza ederken medh, fahr, risa gibi eski konuların yanı sıra yaşadığı zamanın tasvirinde işgal, toplumsal yozlaşma ve siyasi karmaşa gibi yeni konuları da şiire katmıştır. Modern şair şahit olduğu yeni ve modern icatların tasvirini yapan değil; çağının ruhunu anlayan, onu beyitlere döküp ifade edebilen, içinde yaşadığı zamanla gelişen, fikirleri ve anlayışı ile çağını yansıtabilen şairdir. ${ }^{1}$. Modern şairin şiirsel tecrübesi sadece kişisel duygularıyla sınırlı değil, aynı zamanda toplumsal tecrübeyle de iç içe olmak zorundadır. Özetle halkların tarihinde ve kültüründe hayat bulan kadim tecrübelerinden istifade etmeli, bu tecrübelerden yola çıkarak yeni bir anlayış ortaya koyabilmelidir.

Modern şiirin sahip olduğu en belirgin özelliklere baktığımızda şiirin temalarında yaptığı değişim ve bu değişime bağlı olarak şiir mefhumunda yaptığı yenileşme dikkatimizi çekmektedir. Zira kadim şiirin konuları ve çerçevesinin bugünün dünyasının ihtiyaçlarını karşılamaktan aciz olduğu düşünülmüştür. Bu sebeple modern şiir geçmişin ötesine uzanıp bugün ve gelecekle sıkı bir bağ kurar. Bir yandan da yaşadığı çağın şahit olduğu farklı kültürel, sosyolojik ve siyasi platformların ona sunduğu bütünsel medeniyet anlayışıyla iç içe olmak zorundadır. ${ }^{2}$

19. yüzyılın sonlarında oluşan toplumsal değişim ve Arap medeniyeti ile Batı arasındaki kültürel temaslar modern edebi akımların oluşmasını sağlamıştır. Kendisinden önceki dönemin birikimlerini alarak sonraki kuşak şairlere yenilikçi bir bakış açısı sunan Dîvan Ekolü bu akımlardan biridir. Bu ekolün temsilcisi olarak Abbas el-Akkâd (1889-1964) örnekliğinde ekolün yenilikçi temalarından olan ümitsizlik temasını ele alacağız. Şairin şiir mefhumunu anlamak için beslendiği tarihi, edebi ve siyasi şartlara kısaca değinilecektir.

Edebiyatın farklı türlerinde eserler veren Abbas el-Akkâd ve onun modern edebiyata etkisi üzerine Arap dünyasında oldukça fazla çalışma bulunmaktadır. Türkçede bu alanda Halit Zavalsiz'in Abbâs Mahmûd el-Akkâd: Hayatı Eserleri ve XX. Yüzyıl Arap Edebiyatındaki Yeri isimli doktora tezinin yanısıra, Emine Direkler'in Modern Arap Edebiyatında Dîvan Ekolü'nün Yeri isimli yüksek lisans tezi ve Salih Zor'un Dîvan Grubunun Modern Arap Edebiyatındaki Yeri isimli yüksek lisans tezi bulunmaktadır. Biz bu makaleyi Dîvan Ekolü şairlerinin şiirlerinde öne çıkan 'ümitsizlik' teması çerçevesinde Akkâd ile sınırlandırdık. Akkâd, Mâzinî ve Şükrî arasında şiirden kopma derecesine getirecek olan tartışmaların yaşanması neticesinde bu ekolün sancağını tek başına taşıyan şair olmuştur. Çalışmamızda öncelikle Dîvan Ekolü'nü oluşturan arka planı, temsilcilerini, ekolün poetikasını ve bu hareketin başlıca özelliklerini tanıttık. Ardından Akkâd şiiri üzerinden, şairin divanından tematik olarak tespit ettiğimiz şiirleri örnekleme yöntemi ile okura sunduk. Bu yolla Arap şiirinin önde gelen şairlerinden Akkâd'ın şiirine ve poetikasına genel bir bakış sunarak mensup olduğu ekolü de ana hatlarıyla tanıtmış olduk. Makalemizde Mâzinî ve Şükrî arasında şiirden kopma derecesine getirecek olan

1 İzzettin İsmail, Şi 'ru'l- 'Arabiyyi 'l-Mu 'âsır, (b.y.: Dâru'l-Fikri'l-Arabî, 2013), s. 14.

2 Cemal Mahmud Seyyid Ahmed Cuneydî, Edebu'l-Arabiyyi' 'l-Hadîs fì Misr-Dirâse Tarihiyye Nakdiyye, (Kahire: Camiatü'l-Ezher, ts.), s. 11. 
tartışmaların yaşanması neticesinde bu ekolün sancağını tek başına taşıyan Akkâd örnekliğinde ümitsizlik temasını inceledik.

\section{Dîvan Ekolü'nün Oluşumunu Sağlayan Tarihsel Süreç}

Arap edebiyatı 19. yüzyıl sonları ve 20. yüzyılın başlarında batılı yazar, eleştirmen ve filozofların da etkisiyle fikir, yazın ve özelikle şiir alanında yenileşme ve ihya hareketine şahit olmuştur. Dönemin içinde bulunduğu siyasi, tarihi, kültürel ve edebi öncüller Batı ile etkileşim oluşmasını sağlamış özellikle Mısırlı edebiyatçı ve aydınların liderlik ettiği ihya hareketleri birçok edebi ekolün oluşmasına imkan tanımıştır.

Muhammed Ali Paşa'nın Mısır'da yönetimi ele geçirmesinden sonra çok sayıda okulun açılması, bu okullarda Fransız ve İngiliz öğretmenlerin göreve başlaması ve birçoğunda yabancı dilde eğitim verilmesi, Batı ile Mısır medeniyeti arasında kültürel bir etkileşim ortamının oluşmasına olanak sağlamıştır. Ardından Napolyon'un Mısır'ı işgaliyle Batının edebi ve fikri mirası Arap edebiyatına aktarılırken matbaaların kurulması, tercüme ve ideolojik hareketlenmeyi teşvik etmiş $^{3}$ ve tüm bunlar modern edebi akımların oluşmasına zemin hazırlamıştır. Edebi akımların oluşmasında rol oynayan bir diğer önemli etken ise tercüme hareketleriyle beraber günlük ve haftalık gazetelerin kurulması olmuştur. Zira bu gazeteler siyasi, toplumsal ve kültürel hayatın dinamikleşmesinde oynadığı rol ile toplumun edebi zevkinin gelişmesine katkı sağlamıştır. ${ }^{4}$

19. yy.da ortaya çıkan Barûdî önderliğindeki Neo-Klasik Ekol, modern şiirin başlangıcı kabul edilmiştir. Barûdî ve en önemli öğrencileri kabul edilen Ahmed Şevkî, Hâfız İbrahim ve Halil Mutrân (1869-1949) Arap mirasının sahip olduğu şiiri, üstün çağlarına geri döndürmeyi amaçlamış; İslamiyeti ve Arap geleneğini çokça yüceltmişler ve bu sebeple oluşturdukları ekol birçok eleştirmen tarafından Medresetü 'n-Nahda (Rönesans Hareketi) olarak isimlendirilmiştir. ${ }^{5}$ Ekolün genel özelliklerine baktığımızda vezin, kafiye gibi şiirin klasik dönemdeki yapısını muhafaza ettikleri görülür. Şiirde medh, risâ, hiciv gibi kadim şiirin sahip olduğu konulara sahip çıkmakla beraber asrın temayüllerini yansıtan kavmi* ve milli duygulara sıklıkla yer vermişlerdir. Bu şekilde halkın hissiyatını, acılarını ve umutlarını dile getirmek suretiyle şiirin konularında nispeten de olsa yeniliğe gitmişlerdir. Aralarında etkilendikleri şairler farklılık göstermekle beraber Batı edebiyatının da oldukça tesiri altında kalan şairler, yer yer romantizm akımına yönelmişlerdir. Diğer taraftan şiirleri; üslubun akıcılığı, ifadenin gücü, manaların açıklığı ve sadeliği, duyguların içtenliği(sıdk) ve ritimlerin güzelliği gibi unsurlarla klasik

3 Cuneydî, Edebu'l-Arabiyyi'l-Hadîs fì Misr, s. 3-10.

4 Süreyya ‘Abdul Men'am Cûde ve İsmail el-‘Abd el-Minşâvî, Nusûs mine'l-Edebi'l-Hadîs, (Kahire: Camiatü’lEzher, ts.), s. 6.

5 Cûde ve Minşâvî, Nusûs mine'l-Edebi'l-Hadîs, s. 9.

* Kavim: Aralarında töre, dil ve kültür ortaklığı bulunan, boy ve soy bakımından da birbirine bağlı insan topluluğu, budun. Kavmi duygular: kişinin içinde doğup yetiştiği topluluğun, kavminin iyiliğine çabalamasını ve savunmasını gerektiren duyguları ifade eder. Bkz. https://sozluk.gov.tr/; https://www.almaany.com/ar/dict/ ar-ar/\%D9\%82\%D9\%88\%D9\%85\%D \% $\% 8 \mathrm{~A} /$ 
dönem Arap şiirleriyle benzer öğelere sahiptir.

Arap edebiyatında Modern şiire asıl yön veren ve eski kalıplarından kurtulmasını sağlayan Abbas el-Akkâd, İbrahim Abdulkadir el-Mâzinî ve Abdurrahman Şükrî’nin temsil ettiği Dîvan Ekolü, hem şiirde hem de tenkit ilminde bir dizi yenileşme gerçekleştirmiş, peşlerinden gelen Apollo ve Mehcer Ekollerine şiirde yenilik açısından öncülük etmiştir. Bu üç şair öncelikle şiirin muhtevasında bir devrim yapmışlar, insana ve duygularına önem vermişlerdir. Sonraki dönemde ise şiirin genel yapısında bir değişime gidilmiştir. Bunlardan biri olan kafiyede yenileşme hareketi, Endülüs'te var olan muvaşşahlara benzer bir yapıda muhammesât (beşli) ve museddesât (altılı) gibi şiir yapılarının icadıyla olmuştur. Nihayet Akkâd'dan sonra gelen romantik şairler serbest şiiri Arap edebiyatının alanına dahil etmiştir.

\section{Dîvan Ekolü’nün Başlıca Özellikleri}

Dîvan Ekolü 20.yy. in ilk yarısının sonlarında özellikle İngiliz kültürü olmak üzere Batı kültürünün tesirinde kalmış, hatta İngiliz Romantizm Ekolü'nden had safhada etkilenmiş bir grup edebiyatçının ortaya koyduğu modern edebi akımdır. ${ }^{6}$ Şiir algıları ve tasavvurları kendilerinden önceki dönemle tamamen farklı olan Şükrî, Mâzinî ve Akkâd üçlüsünden oluşan Dîvan Ekolü, kendilerinden sonraki Arap şiirine farklı bir bakış açısı kazandırmıştır.?

Akkâd "Şevki'den sonra gelen nesil eski Arap edebiyatına hiç benzemez çünkü Ingiliz edebiyatının içinde doğmuştur"» der. Bu üç şair o dönemde tüm Arap dünyasında olduğu gibi İngiliz edebiyatçı ve şairleri okudular. İngiliz tenkitçilerinin tesirinde kaldılar. Akkâd'ın da ifade ettiği üzere hiç şüphesiz Alman, Rus, İtalyan, İspanyol ve Eski Latin edebiyatından da faydalandılar ama bu edebiyatların hiçbiri, İngiliz edebiyatının Arap edebiyatına şiirde ve yazı sanatında yarattığı etkiyi gerçekleştiremedi. Döneme damga vuran İngiliz edebiyatı eleştirmeni Hazlitt ${ }^{9}$ 'in fikirlerinin yansımalarını modern edebi ekollerde görmekteyiz. Dîvan ekolüne modern eleştiride şiirin manası, sanatları, yazının konuları, karşılaştırma konuları ve delil getirme gibi özelliklerini kazandıranın yine Hazlitt olduğu muhakkaktır. 20. yy.ın sonlarında yaşayan edebiyatçılar Hazlitt'in eserlerini okuyup öğretilerini söylediler. Hatta vatanında kendi toplumunun çoğunluğu tarafından kabul görmediği süreçte dahi ona teveccüh

\footnotetext{
Yalar, Modern Arap Şiiri: Kavram-Kaynak-Yapı, (Bursa: Arasta Yayınları, 2003), s. 94.

Cûde ve Minşâvî, Nusûs mine'l-Edebi'l-Hadîs, s. 58.; Yalar, Modern Arap Şiiri: Kavram-Kaynak-Yapl, s. 34. Abbas Akkâd, Şuarâu Mısr ve Bîatuhum fi 'l-Cîli 'l-Mâzi, 2 ed., (Kahire: Mektebetü’n-Nahdati'l-Misriyye, 1950), s. 192.

9 William Hazlitt (1778-1830) İngiliz denemeci. Büyük felsefi problemleri çözmeye ve insan eylemini temellendirecek yeni bir sistematik düşünce ortaya koymaya çalışır. William Godwin ve Rousseau'nun etkisiyle kaleme almış olduğu siyasal denemeleri İngiltere'de monarşiye karşı yazılmış en sert eleştirilerden bazılarını içerir. Hazlitt kalemiyle edebiyata siyasi bir nitelik kazandırmış, tiranlığa karşı özgürlük ruhunu temsil etmiştir. Bkz. Yağız Ay, "William Hazlitt Ve Estetik Eleştiri," Birikim Dergisi (2017), erişim 15 Ağustos 2021.
} 
ettiler. Hazlitt “düşüncenin özgürlüğ̈̈" Akkâd, Mâzinî ve Şükrî üçlüsünden oluşan bu Mısırlı ekol İngiliz edebiyatının bir taklidi olmamış ama hazırlık sürecinde onun 1şı̆̆ından istifade etmiştir. ${ }^{11}$

18. yy. sonları ve 19. yy. başlarında Arap edebiyatına Amerikan-İngiliz fikrinin baskın olduğu Akkâd ve arkadaşlarının kurduğu ekol, Fransız ve ardından İngiliz işgalinin getirdiği toplumsal ortam sebebiyle, kendi toplumları ile aralarında hiç de küçümsenmeyecek mesafeleri olan Batı kültürünün kucağında doğmuştu.

Akkâd ve arkadaşları tarafından yer yer sezgi medresesi olarak anılan bu akım², Akkâd ve Mâzinî'nin beraber çıkardığı ve içerisinde eleştirel görüşlerine yer verdikleri Küteyyibu'dDîvân (Dîvan Risalesi) isimli eser sebebiyle Dîvan Medresesi olarak anıldı. ${ }^{13}$ Şair, edebiyatçı ve edebi eleştirmen vasıflarını bünyesinde barındıran bu üç arkadaşın kurduğu Dîvân Ekolü, şiire ve edebiyata dair yazdıkları makaleler ve güçlü söylemleriyle Modern Arap edebiyatı'na büyük katkılar sağlayacağını vadediyordu. Ancak grup kuruluşunun üzerinden çok geçmeden ed-Dîvân fi 'n-Nakd ve'l-Edeb adlı eserin ikinci cildinin 1921 yılında çıkmasıyla dağılmıştır. ${ }^{14}$ Bunun başlıca nedeni, Şükrî ile Mâzinî arasında çıkan intihal tartışması ve akabinde meydana gelen bir takım karşılıklı eleştiriler sonucunda bu tartışmanın giderek büyümesiyle birlikte grup üyeleri arasındaki bağın zayıflamasıdır. ${ }^{15}$

Şükrî ile Mâzinî arasındaki bu tartışma, Şükrî’nin Dîvanının beşinci cildinin mukaddimesinde, Mâzinî’nin İngiliz şiirinden çok fazla intihal yaptığı suçlamasıyla başlamıştır. Şükrî, intihal olduğunu iddia ettiği bu şiirlerin hangileri olduğunu açıklamış ve asıl kaynaklarını göstermiştir. Ardından Mâzinî'nin Sanemu'l-Elâ '̂̂b adlı eserinde iddialara cevap vererek Şükrî’yi eleştirmesi neticesinde, Şükrî ve Mâzinî edebiyatı bırakmıştır. Bu olaylar sonrasında Akkâd grup içerisinde yalnız kalmıştır. ${ }^{16}$

Dîvan Ekolü'nün başlıca özellikleri şöyledir ${ }^{17}$ :

- IIfadede sadelik: Şiirde kullanılabilecek sözleri belli kriterlere göre sınırlandıran 'elmu'cemu 'ş-şi'rî' (şiir sözlüğü) kalıbı, Dîvan Ekolü şairlerinin itibar ettiği bir alan olmamıştır. Onlara göre şiir yazarken uygun olan veya olmayan kelimeler diye bir ayrım yoktur. Şöyle ki, 'şiire uygun müfredat-şiire uygun olmayan müfredat' sınıflandırmalarını kabul etmemişler ve günlük hayatta yaygın olarak kullanılan kelimeleri şiirlerinde kullanmaktan imtina etmemişlerdir.

10 Hazlitt 1806 senesinde yayınladığı William Pitt ve hükümetinin dış politikasına bir saldırı mahiyetinde olan Free Thoughts on Public Affairs kitabını yazmış ve ‘düşüncenin özgürlüğ̈̈’ fikrini savunmuştur. Bkz. Mark Alan Garnett, "The Political Ideas of William Hazlitt (1778-1830)”, (Yüksek Lisans Tezi, Durham University, 1990); John Simkin, "William Hazlitt," Spartacus Educational, erişim 15 Ağustos 2021.

11 Akkâd, Şuarâu Misr ve Bîâtuhum fi'l-Cîli'l-Mâzi, s. 192.

12 Akkâd, Şuarâu Misr ve Bîâtuhum fi'l-Cîli'l-Mâzi, s. 193.

13 Cuneydî, Edebu'l-Arabiyyi'l-Hadîs fì Misr, s. 66.

14 Salih Zor, "Dîvân Grubu'nun Modern Arap Edebiyatındaki Yeri”, (Yüksek Lisans Tezi, Uludağ Üniversitesi, 2017), s. 29.

15 Cûde ve el-Minşâvî, Nusûs mine'l-Edebi'l-Hadîs, s. 61.

16 Zor, "Dîvân Grubu'nun Modern Arap Edebiyatındaki Yeri”, s. 30.

17 Cûde ve el-Minşâvî, Nusûs mine'l-Edebi'l-Hadîs, s. 58. 
- $\quad$ Manayı, lafız ve sîgaya (şiirsel akışa) üstün tutmuşlardır. Bu şairlere göre şiirde mana, kişinin duyguları, görüşleri, tecrübeleri ve iç dünyasıdır.

- $\quad$ İnsan ruhuna en küçük detaylarına kadar önem vermişlerdir. Bir önceki Neo-Klasik Ekolün aksine krallar, vezirler veya yöneticilere övgü şiirleri yazmamışlardır. İnsan ruhunun derinliklerine inerek onu açık ve ayrıntılı şekilde tasvir etmişlerdir. Bu sebeple şiirleri vicdân̂́-zâtî (sezgisel-öze ait), üyesi oldukları ekol ise yer yer Vicdân Medresesi olarak da isimlendirilmiştir.

- $\quad$ Şiirde çok fazla tabiat tasvirine yer vermiş, duygular ve tabiatı teşbihlerinde sıklıkla bir arada kullanmışlardır.

- Kötümserlik ve ümitsizlik temaları şiirlerinde fazlaca yer almıştır. İngiliz romantik akım, başlangıçta ümitsizlik temasına sahip değilken Fransız romantik akımın etkisiyle zamanla şiirde yer bulmuştur. Whitman ve Thomas Hardy'nin temsil ettiği romantik ekolün etkisiyle Dîvan Ekolü’ne de aynı ümitsizlik teması sirayet etmiştir.

- $\quad$ Şiirde vahdetü'l-kasîdeye önem vermişlerdir. Şükrî şu sözlerle vahdetü'l-kasîdeye davet eder:

"Beyitin klymeti, manası ve kasidenin konusu arasındaki bağla ölçülür. Çünkü beyitler birbiriyle mütekamil olan parçalardır. Beyitlerin kasidedeki konumundan bă̆ımsız şâz ve istisnâ̂ manaları içermesi doğru olmaz. Kasideye müstakil beyitler olarak değil bir bütün olarak bakmak gerekir." 18

Aynı fikir Akkâd'da daha açık ifade bulur:

"Kasidenin tam, sanatsal bir iş olması icap eder. Tıpkı bir heykelin uzuvları ile, bir müzik bestesinin notalartyla kemale ermesi gibi kaside de ancak birbiriyle mütecanis duygu ve hislerin tasviriyle kemale erer. Zira şairin durduğu konum değiştiğinde yahut bütünü ayakta tutan temel sarsıldı̆̆ında sanatsal bütünlüğe halel gelir ve bozulur. Şiir kasidesi yaşayan bir bedendir. Her bir bölümü bedenin sistemlerinden birinin yerini tutar. " 19

- $\quad$ Arap kasidesinde var olan vezin ve kafiye kalıplarından kurtulma çabası: Şükrî, şi'rü'l-mürsel denilen vezinsiz ve kafiyesiz şiirde eserler yazmıştır. Akkâd ise hayatının gençlik dönemlerinde mürsel şiiri kullanmış ancak bir süre sonra bu fikrinden vazgeçmiştir. Çünkü Arap şiirinin ritminin kafiyeden soyutlandığında estetik değerini yitirdiğini savunmuştur.

Birçok ekolde görüldüğü gibi kendi tutum ve felsefelerini açıklama yoluna gitmiş, bunu yaparken kendilerinden önceki ekol ve şairlerle çatışmaya girmişlerdir. Dîvan Ekolü şairleri de edebi tenkit sahasında muhafazakar ekol ile arasındaki edebi kavgalarıyla gündeme gelmiştir. Bu edebi kavga, Akkâd'ın 1909'da Hâfız İbrahim ve Ahmed Şevkî'yi eleştirileriyle başlar. Şükrî, Mâzinî ve Akkâd'ın kaleme aldıkları divanlarının mukaddimelerinde Dîvan Ekolü'nü öven, diğer taraftan muhafazakar ekolü yeren yazılarıyla birlikte, bu kavga daha da büyümüştür.

Dîvan Ekolü şairleri genel manada Arap edebiyatında, özelde ise Arap şiirinde oldukça kısa bir sürede manaya ve olayların derununa ulaşmaya verdikleri ehemmiyetle Batı edebiyatından

18 Abdurrahman Şükrî, Dîvânu Abdurrahman Şükrî, (Kahire: Meclisu'l-A'lâ li's-Sekâfe, 2000), s. 5; Dîvânu Abdurrahman Şükrî (Kahire: Matbaat Zuhrân, 1970), s. 366.

19 Abbas Akkâd, Fusûl mine'n-Nakd 'inde'l-Akkâd, (Kahire: Maktabatu'l-Khanjî, 1969), s. 79. 
süzdükleri modern bakış açısından yola çıkmak suretiyle 'fikir' ve 'duygu'yu sentezleyerek şiiri tüm sınır ve tariflerin ötesine taşımışlardır. Bunu yaparken en önemli rehberleri ise duyguların samimiyeti olmuştur. ${ }^{20}$

\section{Abbas el- Akkâd'ın Şiirinde Ümitsizlik Teması}

Akkâd'a göre, şiirin kaynağı ve amacı şiirin mîyârıdır. Bu da şairin kendisi ve özüdür. Şiir, insanın zatından fışkırır ve ona etki eder. Şiirin hakemi de yine kişinin kendisidir. ${ }^{21} \mathrm{Bu}$ açıdan bakıldığında Akkâd'ın görüşlerinin zevki ve fitri tenkit diye tanımlanan klasik dönem tenkit nazariyelerine bir dönüş olduğunu söyleyebiliriz:

"Şiire; duyguların kişi üzerindeki tesiri, suretlerin hayalimize resmettiği şeyler, duyularla hissettiğimiz, sinırl fikir gözümüzle ortaya konan veya gizemli hayatın ve insani tasvirlerin bize ulaştırdı ̆̆ şeyler olarak bakmamız gerekir. "’2

Bu manaya ulaşmak için de şair ve okur arasında duygusal bir bağ kurmak mecburidir. Usta bir şair bunu gerçek, samimi duygularının bir tezahürü olarak, yarattığı güzel kelimelerle gerçekleştirirken, bu amaç şairi aşar ve artık okuyucunun da amacı haline gelir. Zira "insanların bir kasideden beklediği gözün ve kulağın bir maratonu koşması değil; o kasideyle aynı duyguyu paylaşabilmektir. "'23

Akkâd'ın şiir mefhumunun ifadesinde apaçık beyan ettiği üzere, samimi duyguların ve kişinin kendisinin bu denli odak noktası haline gelmesini beklediği bir şiirde ele aldığı konuların neden bir halifenin, bir emirin veya bir şahsiyetin methinden bağımsız olduğu aşikardır. İşte bu saiklerle şiirlerinin herhangi bir ideolojinin veya bir görüşün savunması olmasını reddetmiş, kendisinden önceki medreseleri bunu yaptıkları için eleştirmiştir. "Şiirden ruhun gerçek adresini göstermesini iste" 24 diyen Akkâd ve arkadaşları şiirin, ruhlarının bir tercümesi olması konusunda çok kararlıydı ve onu medh, hiciv, risâ, gazel ve vasıf gibi konulara ayıran klasik takdimden arındırdılar. Bu tür şiirleri eskilerle kıyaslandığında oldukça nadir yazdıklarını görmekteyiz.

Büyük umutlar vadeden Fransız ihtilalinin beklenen özgürlükçü, demokratik ve refah hayatı verememesi sonucunda yaşanan hayal kırıkları, Mısır'ın Osmanlı Devleti'nden uzaklaşması neticesinde Fransız işgali altına girmesi, ardından 1882'de İngilizlerin işgaliyle toplum, siyasi bir bilinmezlik ve çıkmaz içine düşmüştür. Duyguların ifadesine bu denli önem gösteren Akkâd ve arkadaşları, dönemin sorunlarını zikretme ve bunlara çözümler üretmeyi ideolojik bir amaç haline getirmişlerdir. Şiirde mihenk taşı olarak savundukları samimi duyguların ifadesi olgusu, toplumun maruz kaldığı sorunları dile getirirken ve bunların aşılabileceği yönünde

20 Abdülfettâh el-Hûlî ve Hâlid Talat, Kadâyâ'ş-Şi'r Fî Mukaddimâti Devâvîni Medreseti'd-Dîvân, (Mansûra: Camiatü'l-Ezher, ts.), s. 456.

21 Hamîd Sidkı ve Hamîd Feşâ, "Mefhûmu'ş-Şi'r 'inde’r-Râfiî ve'l-Akkâd (Dirâse Tahlîliyye)," İâât NakdiyyeFasliyye Muhakkama, c. 3, no. 10 (2013), s. 35.

22 Seyyid Kutub, Kütüb ve Şahsiyyât, 3. Bask1, (Kahire: Dâru'ş-Şurûk, 1983), s. 50.

23 Abbas Akkâd ve Abdülkadir el-Mâzinî, ed-Dîvan fi'l-Edeb ve'n-Nakd, 4. Bask1, (Kahire: Dâru'ş-Şa 'b, 1997), s. 20 .

24 Abbas Akkâd, el-Mecmû 'atü'l-Kâmile li-Müelleffâti'l-Üstâz Abbas el-Akkâd: Sấ 'ât Beyne'l-Kütüb, 1. Bask1, (Beyrut: Dârü'l-Kütübi’l-Lübnânî, 1984), 26:208. 
topluma güç verdiklerinde hissedilmektedir. Şiir onlar için kitleleri eğitme, umut verme, acılarını paylaşmanın ifadesinde kullandıkları bir araçtır. ${ }^{25}$ Buna rağmen Akkâd ümitsizliği ve yaşamın içinde bulduğu hayal kırıklıklarını şiirlerinde ifade eder. Şiirlerinde melankoli, ümitsizlik ve hüzün hakimdir. Ancak toplumda hedeflediği misyona ulaşmak için ümitsizliğe saplanıp kalmak yerine gelecek güzel günlere olan inancını da zikretmiş, hayaller kurmuş, umutlar kurgulamıştır. Kendi hayat hikayesini kaleme aldığı Ene (Ben) isimli kitabında yer alan 'Beyne'l-emel ve'l-ye's'(Ümit ve Ümitsizlik Arasında) başlığı şairin, ümitsizlik ve hüsranlar karşısında pes etmediğinin kişisel hayatındaki tezahürü olarak karşımıza çıkar. İşte bu sebeple beyitlerinde yer alan ümitsizliğin ardından şiirle dönüşümünü hedeflediği acı çeken, ezilen kitlelerin sorunlarını dile getirerek onlara umut pompalamıştır.

Bu medresenin özelliği bu şair topluluğunun acziyet, hayallerin boşa çıkması ve hayatın realitesini derinden hissetmiş olmalarıdır. ${ }^{26}$ Abdurrahman Şükrî arzularından ve bu arzuların boşa çıkmasından şöyle bahseder:

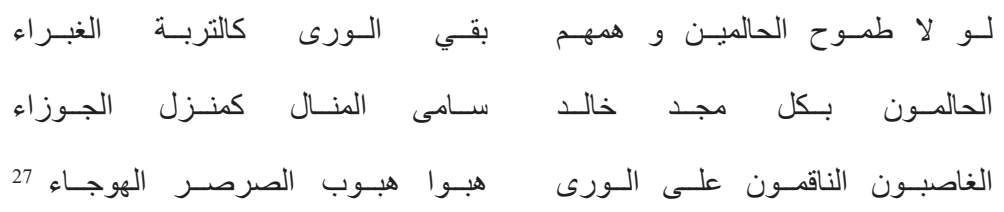

Hayalleri olanların arzuları ve endişeleri olmasaydı

Insanlık tozlu bir toprak gibi kalırdl

Bütün ebedi şereflerin hayalini kuranlar

Yıldızların yanına zirvelere yükseldi

Insanlardan gasp edenler ve intikam alanlar

Silip süpürdüler şiddetli bir firtına misali

Mâzinî ümitsizliğin zirvesine şu beyitlerde ulaşmıştır:

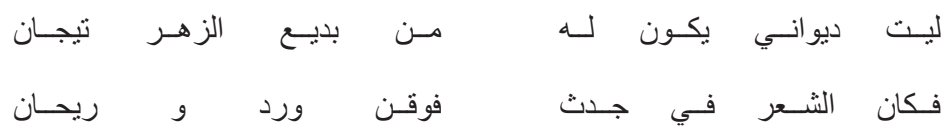

25 Emine Direkler, “Modern Arap Şiirine Dîvan Ekolü’nün Yeri”, (Yüksek Lisans Tezi, Ankara Üniversitesi, 2017), S. 53.

26 Cuneydî, Edebu'l-Arabiyyi'l-Hadîs fì Misr, s. 67.

27 Şükrî, Dîvânu Abdurrahman Şükrî, Matbaat Zuhrân, s. 298. 


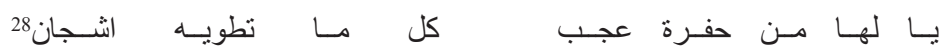

Şiirim ah keşke onun olsaydı

En harika çiçeklerden taçları

Şiir kabirde kald

Üzerinde gül ve reyhan

Ne tuhaf bir çukur

Örtüsü sadece dallardan

Aynı ümitsizliği Akkâd'ın dilinde insanları anlatırken görüyoruz:

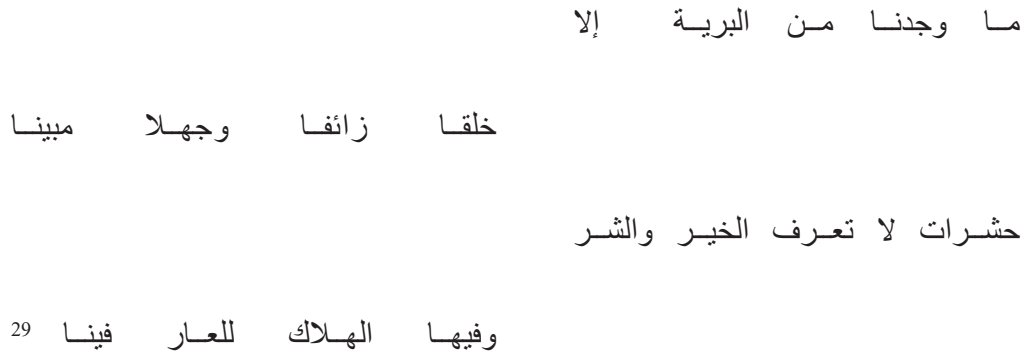

Mevcudat ki içinde yok

Sahte bir ahlak, apaçık bir cehaletten gayrısı

Haşerat ki ayıramaz iyiliği kötülükten

Bunda var helak, o da ayıbımızdan ötürü

Şükrî, Mâzinî’yi İngiliz şiirinden intihal yapmakla suçlarken her ikisi de birbirine beyitlerle saldırmıştır. Aynı pesimist düşünce dostluk üzerinde yansımasını göstermiştir:

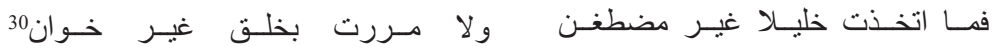

Hiçbir dost edinmedim ki kindar olmasın

Hiçbir kulla yürümedim ki hain olmasın

28 Abdülkadir Mâzinî, Dîvânu'l-Mâzinî, (Kahire: el-Meclisu'l-A'lâ li's-Sekâfe, 1999), s. 71.

29 Abbâs Akkâd, Dîvân min Devâvîn, (Kahire: Nahdatu Misr li't-Tıbâa ve'n-Neşr ve't-Tevzî, 2001), s. 12.

30 Şükrî, Dîvânu Abdurrahman Şükrî, Matbaat Zuhrân, s. 222. 
Şükrî’nin şiirinde ümitsizlik bir adım öteye ulaşmış ve kendisini hayatta kaderin akışı içerisinde iradesi olmayan bir kukla gibi resmetmiştir:

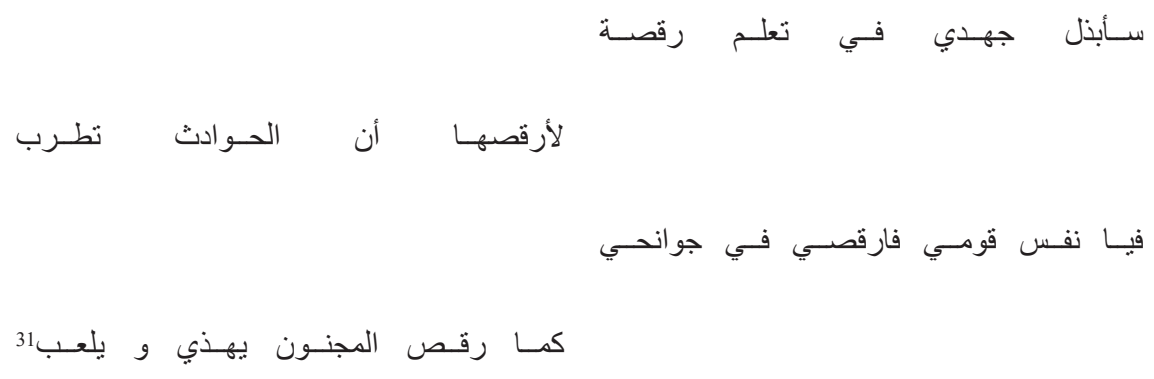

Tüm çabamı sarf edeceğim öğrenmeliyim bir dans

Oynamak için çünkü olaylar çallyor müziği

Ey nefsim kalk kaburgalarım dans et

Oynayıp saçmalayan mecnunun raksı gibi

Dîvan ekolü, şairin şahsiyetinin belirdiği vicdânî şiire yönelmiştir. Bu ekolün şairleri arasındaki mizaç, kültür ve hayat şartlarındaki bariz farklılıklara rağmen, hepsi şiirin mevzularını duygularıyla renklendirerek mısraları şahsi görüşlerinin ifadesinde kullanmışlardır.

Ekolün en önemli özelliklerinden biri -Akkâd hariç- şiirden zamanla uzaklaşma olmuştur. Mâzinî şiiri bırakmış Şükrî ise yine nesre yönelmiştir. Bu üç şair vicdanın manası hakkında ihtilafa düşmüştür. Mâzinî vicdanın grubun içinde farklılıkları buluşturan aktör olduğunu düşünür. Ve şöyle der: "Şiir zihinsel bir sanattır. Amacı duygu, icrası hayal veya duyguyla yönünü belirleyen birbiriyle bağlantılı hatıralardır. "32

Akkâd ise vicdana karşı fikirsel şiiri savundu. "İnsanın meziyeti düşünürken hissetmesi, hissederken de düşünmesidir" ${ }^{\text {33 }}$ der. Ona göre, eğer şair kalbiyle düşünmeyi ve aklıyla hissetmeyi başarırsa şiiri 'iyi şiir' olur. Aksi takdirde şiiri soğuk, karmaşık ve muğlak bir nesirden ibarettir. Tüm bu fikirselliğine rağmen Akkâd'ın şiirinde yoğun hislerinin resmettiği ümitsizliği görürüz:

31 Şükrî, Dîvân-u Abdurrahman Şükrî, Matbaat Zuhrân, s. 152.

32 Abdülkadir Mâzinî, eş-Şi 'r: Kâyâtuhu ve Vesâituhu, 2. Baskı (Kahire: Dâr'us-Sahve, ts.), s. 3-72.

33 Muhammed Mendûr, eş-Şi 'r'ul-Misrî Ba'de Şevkî, 1. Baskı, (Kahire: Nahdatu Misr li't-Tıbâ'a ve'n-Neşr ve’tTevzî, 2003), s. 56. 


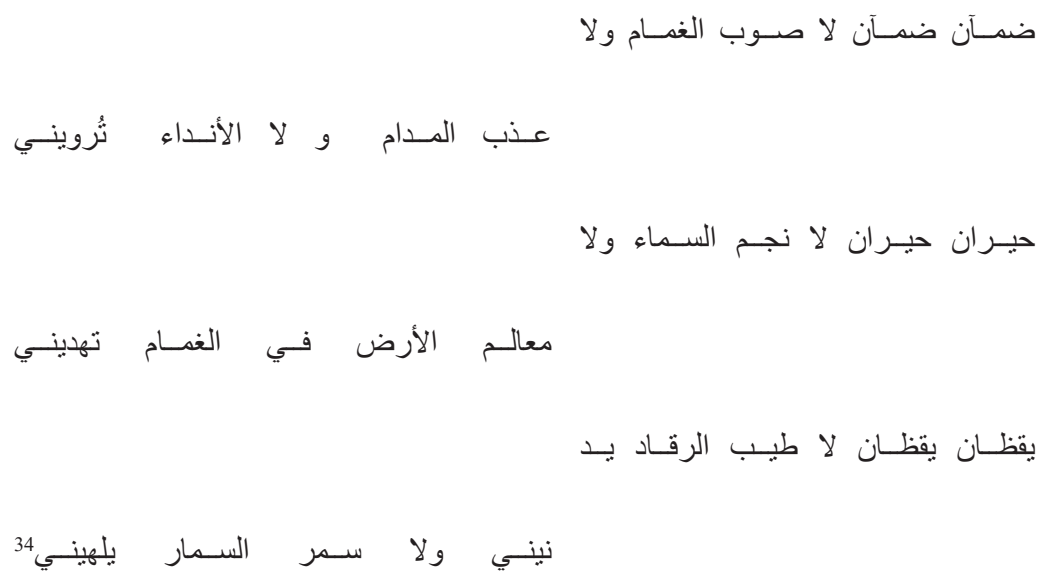

Susuz susuz, yok bulutta bir damla

Yok şarabın güzel tadı, yok çiy beni ıslatacak

Şaşkın şaşkın, yok gökte yıldız

Yok yeryüzünün simgeleri bulutlarda beni doğruya ulaştıracak

Uyanık uyanı, yok uykuda rahatlı

Beni yanaştıran, yok gece sohbetlerinden beni oyalayacak

Akkâd'a göre şairin şiir tecrübesinde vicdani doğruluk olması şarttır. Yani şair kendi nefsinde bulduğu hakikati ifade eder ve ona inanır. Ayrıca mevzusu bayağı ve kıymetsiz olan tecrübelerden şiir yazılmaz. Ne zaman ki şair onlara kendi güçlü duygularından, hayallerinden ve tasvirlerinden eklerse onlardan güzel ve sezgisel manalar çıkarmayı başarır. Şiir melekesinin gücüyle etrafındaki olaylara hayalinden taşanları, duygularından çıkanları eklediğinde günlük olayları anlatan mısralar dahi sanatsal bir söze dönüşebilir. ${ }^{35}$ Bunun örneğini yine Akkâd'ın kendi şiirinde görürüz:

34 Şevkî Dayf, el-Edebu'l- 'Arabiyyu'l-Mu 'âsır fì Mısr, 3. Baskı, (Kahire: Dâru'l-Meârif, 1971), s. 143.

35 Muhammed Ganîmî Hilal, en-Nakdu'l-Edebiyyu'l-Hadîs, (Beyrut: Dâru'l-'Avde, 1973), s. 387. 


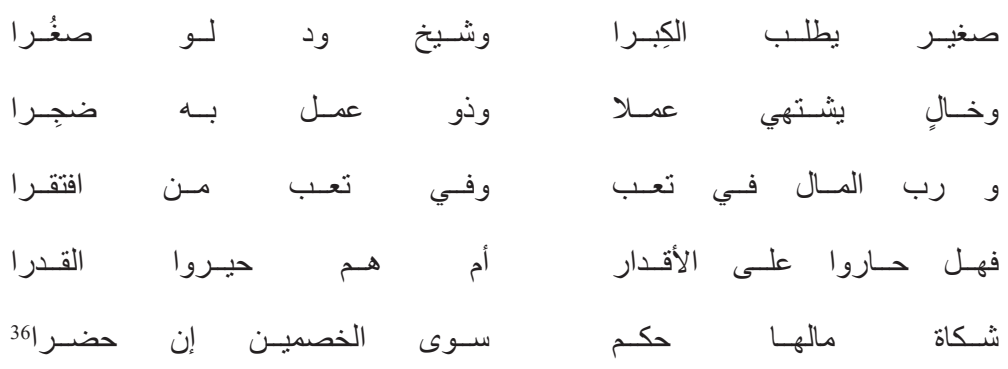

Küçük büyümek ister

Ihtiyar küçülmek diler

Boş gezen iş arzular

Işi olan sıkıntıdadır

Mal sahibi yorgundur

Fakir fukara yorgun

Kaderlerine mi şaştılar

Yoksa kaderi mi şaşırttılar

Şikayetin hükmü yoktur

Ve iki hasımdan başka geleni

Yukarıdaki beyitlerde Akkâd, aslında hayatın herkese farklı bir sıkıntı gösterdiğini, toplumsal refah olarak görülen mal ve mülk algılarının dahi zengin veya fakirde olumsuz yönleri olduğunu ifade eder. Hayatın içerisindeki handikapları, ikilemleri anlatırken, şikayet edilen davada, iki düşmanın varlığından başka bir gerçeğin olmadığını ifade eder. Bunca koşturmaca ile akıp giden hayatın içinde tartışmanın ve kavganın bir değeri veya kazananı da yoktur. Kavgadan geriye sadece davalı ve davacı, iki düşman kalır. Öyleyse manasız ve boş kavgaların peşindeyiz. Bu bakış açısı ayette buyurulduğu üzere:

"و وما هذه الحياة الدنيا الّّ لهو ولعب" (Bu dünya hayatı sadece bir eğlenceden, oyundan ibarettir) ayetini hatırlatmaktadır. Zira dünya hayatı ahirete kıyasla faydası çok azdır. Şikayet ve kavga da bu oyun ve eğlencenin bir parçasıdır. Bu düşünce insanın varoluşundan itibaren zihnini kurcalar. Öyle ki Eflatun "Varlık yoktur. Somut duyularımızla algıladıklarımız sadece bir

36 Akkâd, Dîvân min Devâvîn, s. 7.

37 "Diyanet Vakfı Meali," 29/64. 
gölgedir" ${ }^{38}$ derken, Mutasavviflar "Lâ mevcûde illa hû" derken yine aynı felsefi düşüncenin ekseninde dolaşır. ${ }^{39}$

Akkâd 'Eşbâhu'l-asîl' isimli Dîvanında yer alan Sirru'd-dehr isimli kasidesinde şöyle der ${ }^{40}$ :

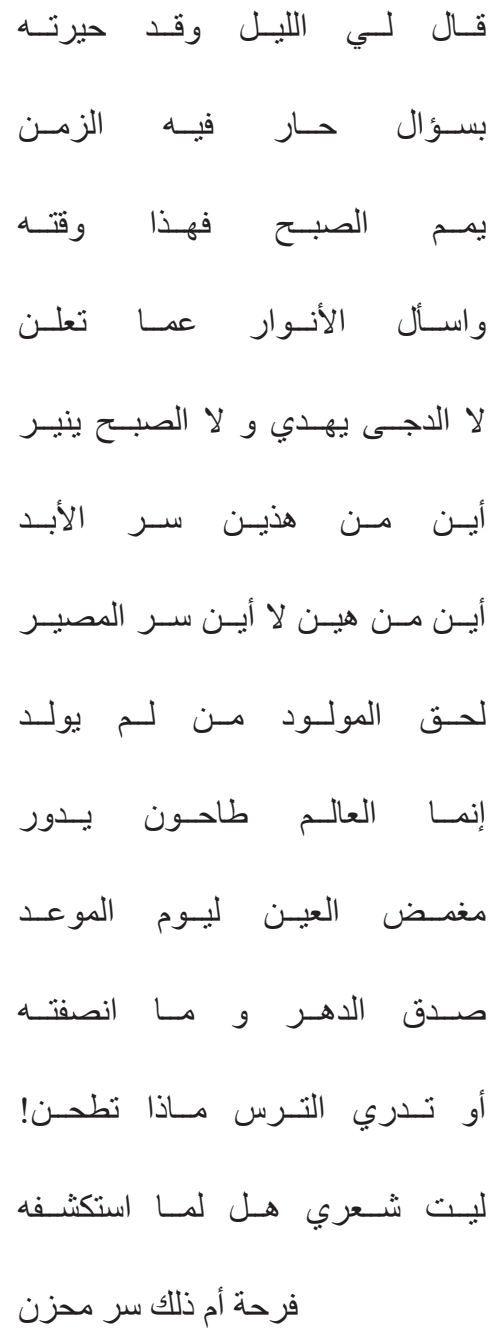

38 Bkz. Eyüp Erdoğan, "Platon ve Aristoles’in Bilimlere İlişkin Sınıflamaları," FLSF Felsefe ve Sosyal Bilimler Dergisi, no. 7 (2009): 137-62; Fahrettin Olguner, "Eflâtun," Türkiye Diyanet Vakfi İslâm Ansiklopedisi, c.XX, (Ankara: TDV Yayınları, 1994), s. 469-76.

39 Bkz.Mehmet Kubat, “İbn Teymiyye’nin İbn Arabî Eleştirisi,” Birey ve Toplum Sosyal Bilimler Dergisi 9, no. 2 (2019); Ethem Cebecioğlu, “Akşemseddin’de Bazı Tasavvufi Kavramlar-I,” Ankara Üniversitesi Illahiyat Fakültesi Dergisi 42, no. 1 (2001).

40 Abbas Akkâd, Dîvânu'l-Akkâd, (Kahire: Matbaatü'l-Me‘âhid, 1921), s. 91. 
Gece bana şöyle dedi, onu şaşkına çevirdiğimde

\section{Zamanı afallatan sualimle}

Sabah aydinland tam vaktiydi

Işıklara sor neyi ilan ediyorlar

Ne gece karanliğl yol gösteriyor ne sabah aydınlatıyor

Bu ikisinden çıkan ebediyet sırrı nerede

Kolay olan nerede, yok gidiş yerinin sırr, hani nerede

Çocuk doğmadı ̆̆ kişiye intisap etti

Alem bir değirmen dönüp duruyor

Gözleri kapalı klyamet gününe dek

Zaman doğruyu söyledi ona insaflı davranmadım

Döndüren farkındadır neyi ögütttüğünün!

Ah keşke bileydim, neyi ortaya çıkaracak

\section{Bir sevinci mi yoksa hüzünlü bir sırrı mı}

Bu mısralarda Akkâd, zamanı dahi şaşkına çeviren sualinden bahsediyor, 'ebediyet sırrı'nın hakikatini bulmaya çalışıyor. Gâh ümitsizliğe kapılıyor, gâh âlem değirmenini döndürenin hakikati bildiğine dair umut taşıyor. Gördüğü karanlığı aralayıp ardından bir 1şık süzmesi beklemesi, derûnunda yaşadığ ikilem, beyne'l-ye's ve'l-emel kavramı mısralarda tezat manadaki kelimelerin bir araya gelmesiyle kendini gösteriyor.

\section{SONUÇ}

19. yy.'ın sonlarında Mısır'da Osmanlı Devleti’nin gücünü kaybetmesi ile yönünü Batıya dönen Mısır'da, ortaya çıkan siyasi ve toplumsal belirsizlikler modern Arap şiiri ekollerinin oluşmasına zemin hazırlamıştır. Batı ve Arap edebi mirasını sentezleyen, İngiliz Romantik Ekolü’n etkisiyle şiirde yeni bir yönelişin kapılarını açan Dîvan Ekolü hem Mısır edebiyatında hem de Modern Arap edebiyatında büyük bir yankı oluşturmuştur. Genel manada Arap edebiyatında, özelde ise Arap şiirinde sürekli birbirini tekerrür eden ve öteye gidemeyen mana ve kalıplardan kurtarmıştır. Böylece kendisinden sonra gelen Mehcer ve Apollo gibi grupların doğuşuna sebep olmuştur. Ayrıca şiir mefhumuna verdikleri mana ve onu kitlelerin fikri ve toplumsal dönüşümü yolunda kullanmaları ile düşünsel ve nakdî anlamda ufuk açıcı 
bir misyon edinmişlerdir. Zira tenkit ilminin parlaması edebiyatın parlaması demektir ve her ikisi birbirini tamamlayıcı niteliktedir. Şiirde hem yapısal yönden hem de fikirsel yönden hayli yenilik yapmışlar ve şïrde Akkâd'ın deyimiyle vicdani doğruluk aramışlardır. Makalemizde Mâzinî ve Şükrî arasında şiirden kopma derecesine getirecek olan tartışmaların yaşanması neticesinde bu ekolün sancağını tek başına taşıyan Akkâd örnekliğinde ümitsizlik temasını inceledik. Şiirlerinde, felsefi ve edebi makalelerinde fikirlerini savunmuş ve acı çeken, ezilen halkların kalemi olmayı sürdürmüştür. Tam da bu sebeple klasik şiirin konuları olan medh, hicâ, fahr, vasf gibi konulardan uzak durmaya çalışmış; toplumun içinde bulunduğu çıkmazı ifade ederken melankoli, hüzün ve ümitsizliğe şiirlerinde yer vermiştir. Şunu da belirtmek gerekir ki, Akkâd'da ümitsizlik teması hayattan kopma derecesinde olmayıp, şair benimsediği Romantizm Ekolü'nün de etkisiyle, kederlerle dolu bir dünyada geleceğin nice umutlar barındırdığını, bu karanlığın ardında özgür, aydınlık bir yarının beklediğini ifade etmiş, güzel günlerin hayalini resmetmiştir. İşte bu sebeplerle şiirinde beyne'l-emel ve'l-ye's dediği; karanlık ve aydınlık, ölüm ve hayat, sevgi ve nefret; ümitsizlik ve umut gibi ikilemleri ve tezatları sıkça bir arada görmekteyiz.

Hakem Değerlendirmesi: Dış bağımsız.

Çıkar Çatışması: Yazar çıkar çatışması bildirmemiştir.

Finansal Destek: Yazar bu çalışma için finansal destek almadığını beyan etmiştir.

Peer-review: Externally peer-reviewed.

Conflict of Interest: The author has no conflict of interest to declare.

Grant Support: The author declared that this study has received no financial support.

\section{Kaynakça/References}

Akkâd, Abbas. el-Mecmû 'atü'l-Kâmile Li-Müelleffâti'l-Üstâz Abbâs el- 'Akkâd: Sâ 'ât Beyne'l-Kütüb. 1. Bask1. 28 cilt. Beyrut: Dâru'l-Kütübi'l-Lübnânî, 1984.

_. Fusûl mine'n-Nakd 'inde'l-Akkâd. Kahire: Mektebetu'l-Khanjî, 1969.

—. Dîvân min Devâvîn. Kahire: Nahdatü Misr li’t-T1bâ‘a ve'n-Neşr ve't-Tevzî‘, 2001.

. Dîvânu'l- 'Akkâd. Kahire: Matba'atü'l-Me‘âhid, 1921.

- Şuarâu Mısr ve Bîatuhum fi 'l-Cîli'l-Mâzi. 2.Bask1. Kahire: Mektebetü'n-Nahdati'l-Misriyye, 1950.

Akkâd, Abbas ve Abdülkadir el-Mâzinî. ed-Dîvan fi'l-Edeb ve'n-Nakd. 4. Bask1. Kahire: Dâru'ş-Şa'b, 1997.

Ay, Yağız. "William Hazlitt ve Estetik Eleştiri.” Birikim Dergisi (2017), erişim 18 Ağustos 2021. https:// birikimdergisi.com/guncel/8346/william-hazlitt-ve-estetik-elestiri

Cebecioğlu, Ethem. „Akşemseddin“de Bazı Tasavvufi Kavramlar-I.“ Ankara Üniversitesi İlahiyat Fakültesi Dergisi 42. no. 1 (2001): 77-95.

Cûde, Süreyya ‘Abdul Men'am, ve İsmail el- ‘Abd el-Minşâvî. Nusûs mine'l-Edebi'l-Hadîs. Kahire: Câmi'atü’lEzher, ts.

Cuneydî, Cemal Mahmud Seyyid Ahmed. Edebu'l- 'Arabiyyi'l-Hadîs fî̀ Misr-Dirâse Târîhiyye Nakdiyye. Kahire: Câmi'atü'l-Ezher, ts.

Dayf, Şevkî. el-Edebu'l-'Arabiyyu'l-Mu 'âsır fì Mısr. 3. Bask1. Kahire: Dâru'l-Me‘ârif, 1971. 
Direkler, Emine. „Modern Arap Şiirine Dîvan Ekolü’nün Yeri.“Yüksek Lisans Tezi, Ankara Üniversitesi, 2017.

“Diyanet Vakfı Meali.”, erişim 18 Ağustos 2021. https://kuran.diyanet.gov.tr/tefsir/Ankeb\%C3\%BBtsuresi/3404/64-ayet-tefsiri

Hûlî, 'Abdülfettâh and Hâlid Talat. Kadâyâ'ş-Şi'r fî Mukaddimâti Devâvîni Medreseti'd-Dîvân. Mansûra: Câmi'atü'l-Ezher, ts.

Erdoğan, Eyüp. "Platon Ve Aristoles’in Bilimlere İlişkin Sınıflamaları.” FLSF Felsefe ve Sosyal Bilimler Dergisi. no. 7 (2009): 137-62.

Garnett, Mark Alan. “The Political Ideas of William Hazlitt (1778-1830).” Yüksek Lisans Tezi, Durham University, 1990.

Hilal, Muhammed Ganîmî. en-Nakdu'l-Edebiyyu'l-Hadîs. Beyrut: Dâru'l-‘Avde, 1973.

İsmail, İzzettin. Şi ‘ru’l- 'Arabiyyi’l-Mu ‘âsır. b.y.: Dâru'l-Fikri’l-‘Arabî, 2013.

Kubat, Mehmet. “İbn Teymiyye’nin İbn Arabî Eleştirisi.” Birey ve Toplum Sosyal Bilimler Dergisi 9. no. 2 (2019): 223-70.

Kutub, Seyyid. Kütüb ve Şahsiyyât. 3. Bask1. Kahire: Dâru’ş-Şurûk, 1983.

Mâzinî, Abdülkadir. Dîvânu'l-Mâzinî. Kahire: el-Meclisu'l-A'lâ li’s-Sekâfe, 1999.

eş-Şi 'r: Kâyâtuhu ve Vesâituhu. 2. Baskı. Kahire: Dâru's-Sahve, ts.

Mendûr, Muhammed. eş-Şi ‘ru 'l-Misrî Ba ‘de Şevkî. 1. Baskı. Kahire: Nahdatu Misr li’t-Tıbâa ve'n-Neşr ve’tTevzî, 2003.

Olguner, Fahrettin. "Eflâtun.” Türkiye Diyanet Vakfi Íslâm Ansiklopedisi. XX: 469-76. Ankara: TDV Yayınları, 1994.

Sıdk1, Hamîd ve Hamîd Feşâ. "Mefhûmu'ş-Şi'r 'inde'r-Râfî̂ ve'l-Akkâd (Dirâse Tahlîliyye).” İdâât NakdiyyeFasliyye Muhakkama 3. no. 10 (2013): 9-41.

Simkin, John. "William Hazlitt." Spartacus Educational (2017). erişim 18 Ağustos 2021. William Hazlitt (spartacus-educational.com)

Şükrî, Abdurrahman. Dîvânu Abdurrahman Şükrî. Kahire: Meclisu'l-A'lâ li’s-Sekâfe, 2000.

. Dîvânu Abdurrahman Şükrî. Kahire: Matbaat Zuhrân, 1970.

Yalar, Mehmet. Modern Arap Şiiri: Kavram-Kaynak-Yapı. Bursa: Arasta Yayınları, 2003.

Zor, Salih. „Dîvân Grubu‘nun Modern Arap Edebiyatındaki Yeri.“'Yüksek Lisans Tezi, Uludağ Üniversitesi, 2017. 